\title{
Effect of fertilization on mineral-element balance in grassland
}

\author{
J. J. LEHR 1, J. GRASHUIS ${ }^{2}$ and E. E. VAN KOETSVELD'2
}

\section{Summary and Conclusions}

In a 14-year fertilization experiment on pasture a study was made of the changes in mineral composition of the soil on the one hand and of grass and hay on the other. The experiment ended with a grazing trial on yearling cattle.

It appeared that on the humic sandy soil of "De Schothorst" the fertilization system now commonly practised in the Netherlands (application of lime ammonium nitrate + rather concentrated muriate of potash + superphosphate or basic slag) sufficiently maintained the level of soil reaction, and, especially with a rather intensive use of fertilizer, also limited the leaching of bases (with the exception of sodium) to a satisfactory extent.

The present system leads, however, to a severe exhaustion of magnesium and sodium, necessitating separate and additional fertilization measures to ensure reasonable contents of these elements in grass and hay.

For magnesium these measures should consist of :

a. raising the magnesium level of the soil to a suitable level,

b. replacement of the yearly withdrawal by an annual of biennial application of $100 \mathrm{~kg}$ kieserite per ha or a dressing of lime ammonium nitrate-containing magnesium.

To improve the sodium supply of sodium-poor pastures it is recommended that the first nitrogen dressing in spring should be given either wholly or partly in the form of Chilean nitrate of soda. Application of common salt (sodium chloride) can be of use in farms with preponderantly organic manuring.

Low calcium contents in grass and hay - rather frequent in the Netherlands - are not necessarily related to an insufficient calcium supply or a negative balance of this element in fertilization, but are possibly dependent on other factors requiring further study.

The application of farmyard and liquid manure as the basis of the fertilization programme with additional application of small amounts of artificial fertilizers appeared to exercise a favourable influence on the botanical composition of the sward and also on the magnesium economy, but could not check the impoverishment in sodium. Moreover, heavy dressings of organic manure lead to a rather excessive supply of potash and phosphate.

\section{Introduction}

Between 1944 and 1958 an experiment was carried out at "De Schothorst" which aimed at studying the effect of grassland fertilization on the soil and the mineral composition of the grass and, via these two factors, on the health and productivity of grazing cattle.

The initiative for this experiment was taken by the late Professor Dr. B. Srollema who, on behalf of the second author (Dr. J. Grashurs who was then director of "De Schothorst"), consulted Professor Ir. J. Hudig and the first author of this paper on its technical implications with regard to fertilization.

1 Plant Nutrition Research Laboratory, Chilean Nitrate Agricultural Service, Wageningen, Netherlands.

2 The Schothorst Institute for Modern Cattle Feeding, Hoogland near Amersfoort, Netherlands.

Received for publication 19th October, 1962. 
The reasons for the experiments lay in the general intensification of grassland management, especially by increased nitrogen fertilization, a trend which had started before the second World War, and in the question whether the transition from the old system, with a very moderate use of artificial fertilizers (in addition to the organic manure), to one involving greater use of inorganic fertilizers would affect the mineralelement economy of the grass. The increasing tendency to use synthetic and concentrated fertilizers also played a part in the problem.

To express the complex character of the experiment and the principle of relationship between the different factors the investigation was named the BPD-experiment (BPD $=$ Bodem - Plant - Dier or Soil - Plant - Animal), a name which was also used later for regional investigations with a wider scope. The concept was characteristic of the comprehensive and far-reaching vision of Professor Srollema on the subject of agricultural science.

From its nature the investigation required relatively large plots of land if it were to be possible to conclude it with a grazing experiment. As a consequence the fertilization scheme had to be kept very simple. For this reason the choice fell on a comparison of organic manure with artificial fertilizers, with the intention of dividing the latter into two treatments, one with fertilizers rich in mineral elements (the socalled ballast materials) and the other with fertilizers poor in mineral elements.

For the first-mentioned group is was planned to use fertilizers like Chilean nitrate (secondary constituent sodium), nitrate of lime (secondary constituent calcium), basic slag (secondary constituents calcium and magnesium), super phosphate (secondary constituent calcium) and muriate of potash containing 20 or $40 \% \mathrm{~K}_{2} \mathrm{O}$; and for the group poor in mineral elements synthetic nitrogen fertilizers (ammonium nitrate, sulphate of ammonia), concentrated potash salts (muriate of potash containing 50 or $60 \% \mathrm{~K}_{2} \mathrm{O}$ ) and double superphosphate were to be used.

On framing the experimental design in greater detail, however, it was found impossible to hold strictly to this original idea, and that for the following reasons:

1. A dressing of 20 to 30 tons per ha of farmyard manure, possibly in combination with 10.0001 of liquid manure, would exceed the practicable limit but would nevertheless give a relatively low nitrogen level which could not easily be raised without altering the original idea of the experiment.

2. Ammonium nitrate was only used in the Netherlands during a short period immediately after the War; it was not obtainable later. Sulphate of ammonia is not a suitable fertilizer under conditions prevailing in the Netherlands. The nitrogen fertilizer generally used in this country for grassland is lime ammonium nitrate and for practical reasons it was decided to use this as a nitrogen source, though it cannot be classed as a fertilizer poor in mineral elements.

3. Owing to the limitations imposed on the nitrogen level by the use of organic manures, the rates of nitrogen could not be as high as those recommended by the State Advisory Service for intensive grassland management (up to $200 \mathrm{~kg}$ of $\mathrm{N}$ per ha).

\section{Execution of the experiment}

\subsection{Treat ments}

I. Inorganic fertilizers rich in mineral elements : Chilean nitrate of soda, nitrate of lime, $40 \%$ muriate of potash (in some years $20 \%$ ), basic slag, superphosphate. 
II. Organic fertilizers : farmyard manure and liquid manure with additions of mineral $\mathrm{N}$ and $\mathrm{K}$ in the same forms as in treatment $\mathrm{I}$ to bring the amounts up to the same levels as in that treatment.

III. Concentrated inorganic fertilizers: lime ammonium nitrate $(20,5 \% \mathrm{~N}+38 \%$ $\mathrm{CaCO}_{3}$ ) and 50 or $60 \%$ muriate of potash, as far as available. Instead of dauble superphosphate as planned, normal superphosphate and occasionally basic slag were sometimes used.

The system of fertilization meant that the amounts of phosphate and potash in farmyard and liquid manure more or less determined the basic dressings of the artificial fertilizer treatments.

The experiment was laid out in 4 blocks of pasture land totalling 3,84 hectares in area. Each block was divided into three equal parts of 32 ares, so that 4 plots were available per treatment.

The soil is sandy with a humus content of 6,5 per cent and in 1944 had an initial $\mathrm{pH}$ of 5,8. It was in a reasonable state of fertility and its contents of exchangeable $\mathrm{K}, \mathrm{Na}, \mathrm{Ca}$ and $\mathrm{Mg}$ at the beginning of the experiment were 20,6-7, 100 and $10 \mathrm{mg}$ per $100 \mathrm{~g}$ of soil respectively (see remark under Analytical investigations); in 1949 the amounts of water and citric acid extractable $\mathrm{P}_{2} \mathrm{O}_{5}$ were resp. 14 and $100 \mathrm{mg}$ per $100 \mathrm{~g}$ soil.

\subsection{Course of the experiment}

The experiment was begun in May 1944 and the first period of 11 years with moderate $\mathbf{N}$ dressings lasted until the end of May 1955. For the next 3 years (June 1955 to May 1958 inclusive) heavier nitrogen dressings were applied.

All blocks were mown for hay in 1946, 1947, 1948, 1949, 1954 and 1956, for drying in 1950 and for silage in 1957; they were grazed after mowing in all cases. Yields were determined only for hay.

As the cattle, particularly the young ones, showed roughness and brownish discoloration of the coat each spring under all three fertilizer treatments, a grazing experiment with yearlings was carried out in 1955. The whole of each block, irrespective of fertilizer treatment, received an application of minor elements, the four treatments being manganous suulphate, cobalt sulphate, zinc sulphate, and a mixture of cobalt sulphate and manganous sulphate. Later on the blocks were made comparable again. In 1958 the investigation was concluded by a grazing experiment with yearlings.

\subsection{Fertilization}

The total amounts of $N, P$ and $K$ applied per ha in treatments $I$ and III in the course of the first period of 11 years were 1140,262 and $1609 \mathrm{~kg}$ respectively; the average annual applications were $104 \mathrm{~kg} \mathrm{~N}, 24 \mathrm{~kg} \mathrm{P}$ and $146 \mathrm{~kg} \mathrm{~K}$ per ha. In the same period the applications of organic manure in treatment II amounted to $188.250 \mathrm{~kg}$ farmyard manure and 95.6001 liquid manure per ha. The amounts of $N, P$ and $K$ supplied in this way were $513 \mathrm{~kg} \mathrm{~N}, 216 \mathrm{~kg} \mathrm{P}$ and $917 \mathrm{~kg} \mathrm{~K}$ in farmyard manure, and $270 \mathrm{~kg} \mathrm{~N}, 5 \mathrm{~kg} \mathrm{P}$ and $548 \mathrm{~kg} \mathrm{~K}$ in liquid manure.

1 Half the amount of $\mathrm{N}$ in farmyard manure and the total amount of $\mathrm{N}$ in liquid manure have been reckoned as active nitrogen. For farmyard manure the estimate of 50 per cent availability of $\mathrm{N}$ is higher than the figure now usually accepted (20 to 25 per cent); despite this no great differences in production have shown up. 
Additional amounts of N, P and $\mathrm{K}$ were supplied in the form of inorganic fertilizers to make the total quantities of the three nutrients equivalent to treatments I and III. In the last 3 years of the experiment (2nd period) the total quantities of $N, P$ and $\mathrm{K}$ applied per ha in treatments I and III amounted to 477,123 and $529 \mathrm{~kg}$ respectively, or average annual applications of $159 \mathrm{~kg} \mathrm{~N}, 41 \mathrm{~kg} \mathrm{P}$ and $176 \mathrm{~kg} \mathrm{~K}$ per ha. In treatment II the quantities of $\mathrm{N}, \mathrm{P}$ and $\mathrm{K}$ applied with $90.000 \mathrm{~kg}$ farmyard manure and 30.0001 liquid manure, amounted to $235,123,371$ and $85,1,160 \mathrm{~kg}$ per ha respectively. The total amounts of $P$ and $K$ were thus equal to those of treatments $I$ and III. The deficit of $N(157 \mathrm{~kg})$ was made good with inorganic fertilizers.

Farmyard manure was mostly applied in July or August and liquid manure in the spring (March or April).

For the purpose of comparison particulars are given below of the average contents of minerals in farmyard manure and liquid manure, computed from available analyses (values in brackets are averages of an incomplete number of figures):

$\begin{array}{cc}\begin{array}{c}\text { Farmyard manure } \\ (\%)\end{array} & \begin{array}{c}\text { Liquid manu } \\ (\mathrm{g} / \mathrm{l})\end{array} \\ 22,9 & (18,8) \\ 0,50 & 2,77 \\ 0,49 & 5,57 \\ 0,12 & (0,053) \\ (0,33) & (0,09) \\ (0,11) & (0,10) \\ (0,075) & (0,71)\end{array}$

\subsection{Analytical investigations}

Before starting the BPD-experiment an investigation was carried out in 1944 to record the initial fertility status of the soil and to determine the degree of uniformity of the blocks and plots.

From 1949 onwards a general sampling of the soil was carried out in May of every second year to establish the changes induced by fertilization and withdrawal by the grass. The last sampling took place in May 1958.

In view of the change in analytical methods the figures for $\mathrm{K}, \mathrm{Na}, \mathrm{Ca}$ and $\mathrm{Mg}$ in 1944 (mentioned above under 2.1) have been adjusted to the final method with extraction of the soil by ammonium acetate/acetic acid $(0,5$ normal $/ 0,5$ molar; ratio soil to liquid $1: 2$ ).

Samples of the harvested hay were analysed for dry matter, sand, $\mathrm{SiO}_{2}$ (in plant), crude protein, $\mathrm{K}, \mathrm{Na}, \mathrm{Ca}, \mathrm{Mg}, \mathrm{P}, \mathrm{S}$. Similar analyses were carried out in grass samples taken in May of the years 1951, 1953, 1955, 1957 and $1958 ; \mathrm{Cl}, \mathrm{Fe}$ and $\mathrm{Mn}$ were also determined and in some cases $\mathrm{Zn}$. The farmyard manure and liquid manure applied in treatment II were analysed regularly and the analyses used for calculation of the nutrients supplied.

Finally the botanical composition of the sward was investigated in May of the years 1949, 1951, 1953, 1955 and 1957.

\section{Results}

Because of the restrictions of the experimental design mentioned in the introduction, the results of the experiment were in some cases less clear cut than those originally 
sought. 'In addition, a grazing experiment with older animals had to be omitted and the experiment with yearlings obviously gave a less accurate indication of changes in the composition of soil and sward.

Although the experiment consequently yielded only limited results, several interesting points came to light, especially regarding the mineral-element balance - potassium, sodium, calcium and magnesium - which will be broadly discussed here.

It should be stated from the outset that very important changes in the composition of the adsorptive complex occurred under the influence of fertilization, but that the composition of the sward followed these changes at a slower pace. This was clearest for the elements magnesium and sodium as is shown by the changes in treatment III :

Decrease in complex

Magnesium

Sodium

(14 years) .......... from 12 to $2,5 \mathrm{mg} / 100 \mathrm{~g}$ from 6,5 to $2 \mathrm{mg} / 100 \mathrm{~g}$

Decrease in hay

(1946 to 1956 incl.) ..... from 0,18 to $0,14 \%$

from 0,12 to $0,08 \%$

Decrease in grass

(1951 to 1958 incl.) ..... from 0,16 to $0,11 \%$

from 0,10 to $0,06 \%$

This indicates that the plant is capable, although only to a very limited extent, of keeping its composition constant. As the animal is also able in some degree to control nutritional unbalances there will be a delay in the effect of certain fertilization measures on the health and productivity of the animal.

It is nevertheless a fact that the present method of fertilization leads to a quick exhaustion of both magnesium and sodium.

\subsection{Mineral-element balance}

An effort was made to set up a balance of minerals for $\mathrm{K}, \mathrm{Na}, \mathrm{Ca}$ and $\mathrm{Mg}$ on the basis of the changes in the adsorptive complex (exchangeable bases), the yield data, the analytical data for hay and grass ${ }^{1}$ and the amounts of elements supplied in fertilization. It was assumed for this purpose that the total production of dry matter of this sandy soil, which is situated rather high and is therefore of only moderate productivity, amounted to $10.000 \mathrm{~kg}$. per ha per year. In the years in which the grass was mown the share of hay was $5.000 \mathrm{~kg}$ (treatment II or III) or $5.400 \mathrm{~kg}$ (treatment I) and of mown grass $4.000 \mathrm{~kg}$ (estimated). The withdrawal by hay and mown grass was furthermore accounted in total, and by grazed pasture as one-fifth, because the mineral elements taken in by grazing animals will largely be returned to the land with the solid and liquid manure. KEMP (1960), for example, found that on average four-fifths of the magnesium from grass is excreted by the animals in the faeces and another part in the urine. For calculating the changes in the soil the sod has been put at $800.000 \mathrm{~kg}$ per ha.

The above assumptions are of course to some extent arbitrary and other factors may be involved which cannot be accounted for here. One uncertainty is in the amount of mineral elements supplied in rain water and leached out again by the same agency. We mention as an example that for Hoogland the yearly supply of $\mathrm{Mg}$ in rain water is estimated at $3 \mathrm{~kg}$ per ha, which would thus mean an extra supply

1 For the contents of grass and hay we had to be satisfied with analyses carried out every alternate year in May. They are averaged for 4 plots, but may of course vary to some extent from the whole-year averages. 
of $42 \mathrm{~kg}$ per ha in 14 years. Obviously, however, an enrichment of the soil in this way can be only expected during the summer season, when no leaching occurs (LEHR and VEEN, 1952), and the supply of $\mathrm{Mg}$ with the rain will not be more than half this amount.

In the following calculations no corrections will be made for gains from rain water as on the whole they do not influence the conclusions.

\subsubsection{Potassium}

During the whole experimental period (14 years) the amount of potassium applied totalled $2138 \mathrm{~kg}$ per ha. For treatment III the withdrawal was calculated as follows :

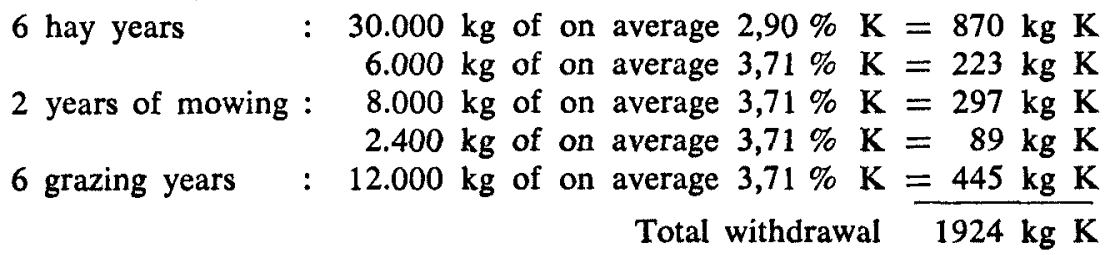

As TABLE 4 indicates, the $\mathrm{K}$ level of the soil of treatment III only showed slight fluctuations in the course of the years (average content $20 \mathrm{mg}$ per $100 \mathrm{~g}$; average fluctuation $1 \mathrm{mg}$ ), pointing to an equilibrium between supply, withdrawal and leaching of $\mathrm{K}$. The losses by leaching can therefore be estimated at $214 \mathrm{~kg}$ or $15 \mathrm{~kg}$ per ha per year and this implies that by far the greater part of the potassium supplied was absorbed by the grass.

In treatment II the withdrawal was practically the same as in treatment III, and it must have been of the same magnitude in treatment $I$ also, despite the lower $\mathrm{K}$ contents of hay and grass, owing to the higher yields of hay. As the $K$ contents of the soil in treatments I and II showed a regular tendency to be higher than in treatment III, this points to a more economic use of $\mathbf{K}$, especially on application of farmyard manure. The leaching losses of $K$ appear to be negligible in these treatments.

\subsubsection{Sodium}

In treatment I the amount of sodium applied in Chilean nitrate of soda and in muriate of potash amounted to $3450 \mathrm{~kg}$ per ha, whereas the withdrawal can be estimated at $174 \mathrm{~kg}$. The content of sodium in the soil did not show a systematic trend (TABLE 4) and ranged from 9 to $18 \mathrm{mg}$ per $100 \mathrm{~g}$.

On the basis of the balance of mineral elements there should have been a yearly increase of well over $20 \mathrm{mg}$ per $100 \mathrm{~g}$ but obviously by far the greater part of the sodium applied has been lost during the winter by leaching.

The amounts of sodium applied in treatment II were $130 \mathrm{~kg}$ per ha with farmyard and liquid manure and $1.000 \mathrm{~kg}$ per ha in inorganic fertilizers. The withdrawal is estimated at $85 \mathrm{~kg}$. In treatment III the amounts applied and withdrawn were 660 and $67 \mathrm{~kg}$ per ha respectively.

Apart from this negative balance there was a fall in the sodium content of the soil from 6 or 7 to $4 \mathrm{mg}$ per $100 \mathrm{~g}$ in treatment II and to $2 \mathrm{mg}$ per $100 \mathrm{~g}$ in treatment III, which also points to severe losses by leaching.

\subsubsection{Calcium}

The calcium balance is less easy to interpret than that of the other mineral elements. In the BPD-experiment large amounts of calcium were supplied by fertilization, 
namely, in superphosphate as mono-, di- or tricalcium phosphate or as calcium sulphate, in basic slag mainly as calcium phospho-silicate and tetracalcium phosphate, and in lime ammonium nitrate as calcium carbonate.

The supply of calcium far exceeded the withdrawal by hay and grass. In the course of the experiment the amounts applied per ha in treatments I, II and III were 1743, 1256 and $1924 \mathrm{~kg} \mathrm{Ca}$ per ha respectively or on average 90 and $138 \mathrm{~kg} \mathrm{Ca}$ per ha per year. Against this the withdrawal (calculated for treatment III) did not exceed $240 \mathrm{~kg}$ per ha in all or $17 \mathrm{~kg} \mathrm{Ca}$ per ha per year.

The fact that the exchangeable $\mathrm{Ca}$ showed an appreciable increase only in treatment I (200 to $300 \mathrm{~kg} \mathrm{Ca}$ per ha), remained nearly constant in treatment II, and even tended to decrease in treatment III in the first period of the experiment suggests heavy losses by leaching.

There are, however, two reasons to doubt this :

1. Calcium in the soil is partly present in a non-exchangeable form and it must be assumed that the calcium supplied in basic slag increases both the exchangeable and the non-exchangeable soil calcium.

2. Calcium in the soil may be fixed by phosphate and this calcium then escapes determination by the normal analytical procedure. In principle five $\mathrm{Ca}$ can be fixed per three $\mathrm{PO}_{4}$ groups to form substances of the hydroxy-apatite type. Compounds such as mono- and dicalcium phosphate can in this way easily revert to less soluble calcium phosphate.

For this reason we do not believe that leaching losses of $\mathrm{Ca}$ were important and we consider the fate of the different calcium compounds may possibly have been as follows :

$\mathrm{CaCO}_{3}$ in lime ammonium nitrate: Conversion into calcium nitrate; the calcium will be partly absorbed by the sward, partly fixed and partly leached out,

Monocalcium and dicalcium phosphate: Only limited absorption of $\mathrm{Ca}$; fixation of appreciable quantities of $\mathrm{Ca}$,

$\mathrm{CaSO}_{4}$ : Partly subject to leaching; some may escape leaching through absorption by the sward (slight) or by fixation (probably of more importance).

\subsubsection{Magnesium}

In the years of the experiment the amounts of magnesium supplied per ha in treatments I, II and III totalled 82,$5 ; 237$ and $18,5 \mathrm{~kg}$ respectively.

For treatment III the balance can be put as follows :

Withdrawal by hay and grass

Supplied in fertilization .... $18,5 \mathrm{~kg}$

Fall of $\mathrm{Mg}$ content of soil . . 60

$85 \mathrm{~kg}$

\section{$78,5 \mathrm{~kg}$}

According to this calculation no magnesium was lost by leaching and as the balance is slightly positive there might have been some supply of $\mathrm{Mg}$ in rain water. The severe depletion of the stock of $\mathbf{M g}$ in the soil is therefore wholly due to withdrawal by the sward.

The withdrawal in treatment II is estimated at $97 \mathrm{~kg}$ and the decline of the $\mathrm{Mg}$ stock in the soil at $17,5 \mathrm{~kg} \mathrm{Mg}$. Here there could have been considerable loss of $\mathrm{Mg}$ by leaching, but it is uncertain whether $\mathrm{Mg}$ in farmyard manure can be deter- 
mined by the extraction procedure for exchangeable $\mathrm{Mg}$. It is likely that magnesium from herbage is converted during digestion into some insoluble inorganic compounds such as magnesium ammonium phosphate. Some of the $\mathrm{Mg}$ in animal faeces is also partly bound by fatty acids (in water-insoluble $\mathrm{Mg}$-soaps (WIND and DEYs). Though in these forms it would not be greatly subject to leaching, its availability to the plant would of course be severely restricted.

In treatment I the figures for withdrawal, supply by fertilizers and fall of $\mathbf{M g}$ content in soil are 98,$1 ; 82,5$ and $44 \mathrm{~kg} \mathrm{Mg}$ per ha respectively, suggesting a leaching loss of $28,4 \mathrm{~kg}$ per ha.

It is however possible that the magnesium in the inorganic fertilizer (here mainly basic slag) is only partly available or determinable. If the availability of $\mathrm{Mg}$ in basic slag is assumed to be 50 per cent, treatments I and III then show positive balances of 13 and $16 \mathrm{~kg} \mathrm{Mg}$ respectively. This could only be explained by a gain of magnesium from rain water. According to our estimate (page $27 / 28$ ) the supply from rainfall in 14 years is about $42 \mathrm{~kg}$ per ha and about one-third of this would thus be fixed by the sward and the remainder leached out.

It follows from the figures that magnesium in the soil can be conserved to a considerable extent by application of farmyard manure, whereas the present system of intensive NPK fertilization severely depletes the magnesium in the soil.

\subsection{Comparison of inorganic with organic fertilization}

Although combined organic and inorganic fertilization is the most usual practice and no strict comparison of organic and inorganic fertilization is possible, it is useful to evaluate them as separate systems. In the BPD-experiment organic fertilization gave better results in some respects without showing clear superiority. In the following paragraphs the effects of the two forms of fertilization will be examined with regard to yield, botanical and mineral composition of grass and hay and to the results of the grazing trial.

\subsubsection{Yield}

No effort has been made exactly to determine the total yield of the different blocks, but the yields of hay in the years concerned have been calculated. On average for the years 1944, 1946, 1947, 1949 and 1954 the total yields per treatment were : I. $6662 \mathrm{~kg}$, II. $6164 \mathrm{~kg}$ and III. $6111 \mathrm{~kg}$. With the exception of one of the 4 plots, which slightly lagged behind probably due to its unfavourable situation (bordered by a row of trees at the south-west side), treatment $I$ yielded more than the other two treatments in all years and all plots.

Obviously no argument against organic manure can be sought in this difference in yield between treatments $\mathrm{I}$ and II, as no strict comparison on an equal $\mathrm{N}, \mathrm{P}$ and $K$ basis is possible, owing to the uncertainty how to assess the activity of nitrogen in farmyard manure.

\subsubsection{Botanical composition}

The results of the botanical investigation carried out by the Plant Ecology Department of the C.I.L.O. (later I.B.S.) at Wageningen can best be given as average marks for quality, namely: $6=$ fair, $7=$ fairly good, $8=$ good (TABLE 1 ).

The organic treatment was thus slightly superior to the two treatments with inorganic fertilizers although the differences were not great. It was significantly better if the five-year averages of the four plots were considered but not if the results of the separate plots were considered per year. 
TABLE 1. Average botanical composition of treatments in BPD-experiment

\begin{tabular}{|c|c|c|c|}
\hline & \multicolumn{3}{|c|}{ Treatment } \\
\hline & I & II & III \\
\hline $\begin{array}{l}1949 \ldots \ldots \ldots \\
1951 \\
1953 \\
1955 \\
1958 \ldots \ldots \\
19 \ldots \ldots \\
\ldots\end{array}$ & $\begin{array}{l}6,9 \\
6,4 \\
7,3 \\
7,1 \\
6,2\end{array}$ & $\begin{array}{l}7,1 \\
6,75 \\
7,4 \\
7,3 \\
7,1\end{array}$ & $\begin{array}{l}6,7 \\
6,3 \\
7,1 \\
7,3 \\
7,0\end{array}$ \\
\hline Average $\ldots$ & 6,8 & 7,1 & 6,9 \\
\hline
\end{tabular}

The cattle showed some preference for the grass of the organic treatment as they grazed it off more closely than that of the inorganic treatments, especially treatment III, which showed rough growth with many tussocks.

\subsubsection{Grazing experiment}

In the final grazing experiment carried out between May 17 and October 4, 1958 with herds of 8 animals no significant differences were found either in state of health or in composition of the blood serum. With the organic treatment the weight increase of the animals was slightly less. For the total period it averaged $104,2 \mathrm{~kg}$ per animal in treatment $I, 93,0 \mathrm{~kg}$ in treatment II and $105,5 \mathrm{~kg}$ in treatment III. As with hay production this should not be regarded as an inferior effect of the organic manure, since the growth of the cattle is dependent, via the grass production, on the rate of application of nitrogen.

\subsubsection{Mineral composition of grass and hay}

TABLES 2 and 3, which give the average composition of hay and of grass for all determinations, show the differences induced by fertilization.

The chief points of interest are the difference in $\mathrm{K}$ and $\mathrm{Na}$ content between treatment $\mathrm{I}$ and II ( $\mathrm{K}$ in treatment II clearly higher, $\mathrm{Na}$ lower), the low $\mathrm{Na}$ content in treatment III and the somewhat higher content of $\mathrm{Mg}$ of the organic treatment in comparison with the inorganic treatments. In fact, the average figures do not do

TABLE 2. Average composition of hay in BPD-experiment in percentages of dry matter

\begin{tabular}{cccccccccccc}
\hline $\begin{array}{c}\text { Treat- } \\
\text { ment }\end{array}$ & $\begin{array}{c}\text { Dry } \\
\text { matter }\end{array}$ & Ash & $\begin{array}{c}\text { Crude } \\
\text { protein }\end{array}$ & $\mathrm{K}$ & $\mathrm{Na}$ & $\mathrm{Ca}$ & $\mathrm{Mg}$ & $\mathrm{K}: \mathrm{Mg}$ & $\mathrm{P}$ & Sand & $\mathrm{SiO}_{2}$ \\
I & $\mathbf{8 2 , 6}$ & $\mathbf{9 , 1}$ & 13,0 & $\mathbf{2 , 7 8}$ & $\mathbf{( 0 , 2 8 )}$ & $\mathbf{0 , 3 7}$ & 0,17 & 16,3 & $\mathbf{0 , 3 5}$ & 0,93 & $(1,76)$ \\
II & $\mathbf{8 2 , 4}$ & $\mathbf{9 , 1 5}$ & 14,0 & $\mathbf{2 , 9 2}$ & $(0,19)$ & $\mathbf{0 , 3 7}$ & $\mathbf{0 , 1 8}$ & $\mathbf{1 6 , 2}$ & 0,355 & 0,74 & $(1,85)$ \\
III & $\mathbf{8 3 , 1}$ & $\mathbf{8 , 9}$ & 13,3 & $\mathbf{2 , 9 1}$ & $(0,11)$ & $\mathbf{0 , 4 2 5}$ & 0,16 & $\mathbf{1 8 , 2}$ & $\mathbf{0 , 3 5}$ & 0,89 & $(1,78)$ \\
\hline
\end{tabular}

TABLE 3. Average composition of grass in BPD-experiment in percentages of dry matter

\begin{tabular}{cccccccccccc}
\hline $\begin{array}{c}\text { Treat- } \\
\text { ment }\end{array}$ & $\begin{array}{c}\text { Dry } \\
\text { matter }\end{array}$ & Ash & $\begin{array}{c}\text { Crude } \\
\text { protein }\end{array}$ & K & Na & Ca & Mg & K:Mg & P & Cl & S \\
I & $(18,0)$ & 11,4 & 18,7 & 3,56 & 0,30 & 0,35 & 0,14 & 25,4 & 0,47 & 1,48 & 0,18 \\
II & $(18,6)$ & 11,7 & 18,5 & 3,74 & 0,11 & 0,35 & 0,15 & 24,9 & 0,47 & 1,16 & 0,20 \\
III & $(18,1)$ & 11,0 & 19,0 & 3,71 & 0,08 & 0,39 & 0,13 & 28,5 & 0,48 & 1,35 & 0,20 \\
\hline
\end{tabular}


sufficient justice to the favourable magnesium effect of farmyard manure as this effect became increasingly clear in the last years of the experiment (see TABLE 4). In 1954 and 1956 the hay showed differences of $0,03-0,05 \% \mathrm{Mg}$ in favour of treatment II, and in 1957 and 1958 the corresponding differences for grass were $0,02-0,03 \%$. The $\mathrm{K}: \mathrm{Mg}$ ratio was also more favourable in the treatment with organic manure.

Finally there is the relatively low $\mathrm{Cl}$ content of the grass of treatment II, which apparently is due to the fact that in this treatment potassium was mainly supplied by organic manure, necessitating only a minor addition of potash salts containing chlorine.

TABLE 4. Trend of mineral-element contents in hay and grass during the BPDexperiment in percentages of dry matter

\begin{tabular}{|c|c|c|c|c|c|c|c|c|c|c|c|c|}
\hline \multirow[b]{2}{*}{ Hay } & \multicolumn{3}{|c|}{$\mathbf{K}$} & \multicolumn{3}{|c|}{$\mathrm{Na}$} & \multicolumn{3}{|c|}{$\mathrm{Ca}$} & \multicolumn{3}{|c|}{$\mathrm{Mg}$} \\
\hline & I & II & III & I & II & III & I & II & III & I & II & III \\
\hline $\begin{array}{l}1946 \\
1947 \\
1949 \\
1950 \\
1954 \\
1956\end{array}$ & $\begin{array}{l}3,09 \\
2,82 \\
2,65 \\
2,62 \\
2,82 \\
2,67\end{array}$ & $\begin{array}{l}2,94 \\
3,29 \\
2,90 \\
2,54 \\
3,01 \\
2,82\end{array}$ & $\begin{array}{l}2,98 \\
3,35 \\
2,87 \\
2,34 \\
3,06 \\
2,83\end{array}$ & $\begin{array}{r}0,26 \\
0,36 \\
0,37 \\
0,15 \\
0,24 \\
-\end{array}$ & $\begin{array}{r}0,29 \\
0,27 \\
0,22 \\
0,07 \\
0,11 \\
-\end{array}$ & $\begin{array}{r}0,12 \\
0,12 \\
0,15 \\
0,08 \\
0,09 \\
-\end{array}$ & $\begin{array}{l}0,39 \\
0,37 \\
0,32 \\
0,48 \\
0,34 \\
0,32\end{array}$ & $\begin{array}{l}0,38 \\
0,39 \\
0,37 \\
0,40 \\
0,37 \\
0,33\end{array}$ & $\begin{array}{l}0,48 \\
0,48 \\
0,36 \\
0,43 \\
0,39 \\
0,41\end{array}$ & $\begin{array}{l}0,19 \\
0,21 \\
0,17 \\
0,18 \\
0,13 \\
0,12\end{array}$ & $\begin{array}{l}0,20 \\
0,18 \\
0,18 \\
0,17 \\
0,17 \\
0,17\end{array}$ & $\begin{array}{l}0,17 \\
0,18 \\
0,17 \\
0,15 \\
0,14 \\
0,14\end{array}$ \\
\hline \multicolumn{13}{|l|}{ Grass } \\
\hline $\begin{array}{l}1951 \\
1953 \\
1955 \\
1957 \\
1958\end{array}$ & $\begin{array}{l}3,58 \\
3,48 \\
3,52 \\
3,49 \\
3,71\end{array}$ & $\begin{array}{l}3,72 \\
3,90 \\
3,81 \\
3,58 \\
3,70\end{array}$ & $\begin{array}{l}3,66 \\
3,81 \\
3,69 \\
3,62 \\
3,75\end{array}$ & $\begin{array}{l}0,26 \\
0,42 \\
0,23 \\
0,29 \\
0,31\end{array}$ & $\begin{array}{l}0,10 \\
0,15 \\
0,08 \\
0,09 \\
0,11\end{array}$ & $\begin{array}{l}0,10 \\
0,10 \\
0,07 \\
0,05 \\
0,07\end{array}$ & $\begin{array}{l}0,45 \\
0,40 \\
0,38 \\
0,24 \\
0,30\end{array}$ & $\begin{array}{l}0,45 \\
0,45 \\
0,36 \\
0,23 \\
0,28\end{array}$ & $\begin{array}{l}0,42 \\
0,48 \\
0,41 \\
0,21 \\
0,35\end{array}$ & $\begin{array}{l}0,19 \\
0,16 \\
0,10 \\
0,14 \\
0,11\end{array}$ & $\begin{array}{l}0,17 \\
0,18 \\
0,12 \\
0,15 \\
0,14\end{array}$ & $\begin{array}{l}0,16 \\
0,16 \\
0,09 \\
0,13 \\
0,11\end{array}$ \\
\hline
\end{tabular}

There are, of course, further points of difference which might be favourable to organic manuring but they were not considered in our investigations. Consideration should be given to the balance of minor elements and to the presence in farmyard manure of organic phosphate and of sulphur compounds which are easily convertible. Although its effect on $\mathrm{Mg}$ content was favourable organic manuring gave an inadequate supply of sodium, and a slightly lower calcium supply than treatment III.

TABLE 5 shows the trend of the mineral-element contents of soil during the course of the BPD-experiment.

TABLE 5. Trend of mineral-element contents in soil of BPD-experiment in $\mathrm{mg}$ per $100 \mathrm{~g}$; averages of four plots

\begin{tabular}{|c|c|c|c|c|c|c|c|c|c|c|c|c|}
\hline \multirow[t]{2}{*}{ Year } & \multicolumn{3}{|c|}{$\mathbf{K}$} & \multicolumn{3}{|c|}{$\mathrm{Na}$} & \multicolumn{3}{|c|}{$\mathrm{Ca}$} & \multicolumn{3}{|c|}{$\mathrm{Mg}$} \\
\hline & I & II & III & I & II & III & I & II & III & I & II & III \\
\hline $\begin{array}{l}1944 \\
1949 \\
1951 \\
1953 \\
1955 \\
1957 \\
1958\end{array}$ & $\begin{array}{l}18 \\
26 \\
25 \\
26 \\
30 \\
20\end{array}$ & $\begin{array}{l}20 \\
18 \\
30 \\
25 \\
25 \\
34 \\
26\end{array}$ & $\begin{array}{l}15 \\
22 \\
20 \\
20 \\
21 \\
19\end{array}$ & $\begin{array}{r}18 \\
10 \\
13 \\
9 \\
16 \\
9\end{array}$ & $\begin{array}{l}6-7 \\
8 \\
4 \\
7 \\
3 \\
5,5 \\
4\end{array}$ & $\begin{array}{l}5 \\
2,5 \\
3,5 \\
2 \\
2,5 \\
2\end{array}$ & $\begin{array}{l}107 \\
112 \\
108 \\
112 \\
119 \\
130\end{array}$ & $\begin{array}{r}100 \\
97 \\
100 \\
84 \\
87 \\
82 \\
99\end{array}$ & $\begin{array}{l}90 \\
84 \\
73 \\
79 \\
90 \\
92\end{array}$ & $\begin{array}{l}9 \\
8,1 \\
5,9 \\
7,8 \\
6,5 \\
4,5\end{array}$ & $\begin{array}{r}10 \\
10 \\
8,3 \\
8,1 \\
11,9 \\
11,9 \\
7,8\end{array}$ & $\begin{array}{l}7 \\
3,5 \\
4,0 \\
4,9 \\
2,7 \\
2,5\end{array}$ \\
\hline
\end{tabular}

Note: Figures for 1944 are estimated. 
3.3. Comparison of inorganic fertilizer treatments (concentrated fertilizers versus fertilizers rich in mineral elements)

As explained in the introduction, practical reasons led to the omission of a treatment consisting of inorganic fertilizers poor in mineral elements. In principle the comparison therefore concerned two inorganic treatments, one coming very close to the normal procedure in practice, and the other with application of fertilizers rich in secondary constituents.

Treatment I gave a fairly regular increase in the $\mathrm{pH}$ of the soil, from $\mathrm{pH}\left(\mathrm{H}_{2} \mathrm{O}\right) 5,8$ to 6,65 in 14 years, and an increase in exchangeable calcium from 100 to $130 \mathrm{mg}$ $\mathrm{Ca}$ per $100 \mathrm{~g}$ soil. The normal treatment III resulted in a slight reduction in the $\mathrm{pH}$ $(5,8$ to 5,5$)$ during the first 11 years of the experiment, but in a rather sharp increase to $\mathrm{pH} 6,2$ on intensification. Parallel to this the calcium content of the soil at first decreased from $100 \mathrm{mg}$ of soil to about $75 \mathrm{mg}$ and then increased again during the last 3 years of the experiment to 92 . These opposite effects will be further discussed under 3.4 .

For the rest the mineral-rich treatment was distinguished by its superior sodium supply, a somewhat improved but still inadequate magnesium supply and a somewhat lower content of potassium in grass and hay, which is also a favourable characteristic. The supply of chlorine was more ample in treatment $I$ than in treatment III.

Despite the lower figures of exchangeable calcium following the normal method of fertilization, this treatment showed somewhat higher contents of $\mathrm{Ca}$ in grass and hay than treatment 1 . The normal treatment left very much to be desired in regard to the magnesium and the sodium supply.

No general and significant differences between the effects of the inorganic treatments on the botanical composition of the sward were evident except that in treatment I Bromus mollis L. was occasionally commoner. This was due in part to the fact that two plots of treatment I were situated on a grass verge from which this species penetrated into the pasture. In May 1957 the frequency of this species in all treatments was exceptionally high, namely, 33; 9,5 and 13,5 per cent respectively in treatments I, II and III, the difference between I and the other treatments being significant. No differences were observed in the grazing trial with yearlings and the increase in weight of the animals was the same for both inorganic treatments.

Reviewing the results for the whole experimental period it can be said that the investigation showed the need to include certain elements, i.e. magnesium and sodium, in the fertilization because the stock of these elements in the soil is either rapidly exhausted by our present system of fertilization, or is insufficient to ensure an adequate supply to the sward. The changes in the soil and in the composition of grass and hay were such that deterioriation in the condition and productivity of the cattle could be expected, certainly in the long run and probably after a short period.

\subsection{Ef fects of intensified fertilization}

In the present investigation nitrogen was applied at two levels averaging 104 and $159 \mathrm{~kg} \mathrm{~N}$ per year per ha. The former is roughly equivalent to the average application of inorganic nitrogen on pastures in the Netherlands today, but it may not quite attain the total level which includes some organic nitrogen. The higher level is well above the present average level of application of nitrogen on grassland.

Several aspects of the intensification of fertilization had to be left out of consideration, such as the influence of increased nitrogen dressings on the yield and the pro- 
tein content of grass, and also problems of rotational grazing and age of the grass. The conclusions mainly refer to the supply of mineral elements and it had already been pointed out that a one-sided system of NPK-fertilization leads to serious shortages in the supply of magnesium and sodium. It is obvious that the process of exhaustion can only be accelerated by intensified fertilization.

A favourable effect of intensification was a better maintenance of the soil reaction with the result that leaching of mineral elements will remain minimal.

The explanation of the opposite tendencies discussed in the previous section is probably closely related to the action of lime ammonium nitrate. Recent research (BoskMA, 1958) has made clear that this fertilizer does not induce appreciable changes of reaction in grassland, but the present investigation suggests that the effect is different for low and high quantities of nitrogen. Low rates lead to a slight decrease of $\mathrm{pH}$ and high rates to some increase. The reason may be that nitrogen at low rates mainly affects the production of grass (greater yields, greater withdrawal of $\mathrm{Ca}$ ), whereas higher rates also influence the $\mathbf{N}$ content (greater withdrawal of $\mathbf{N}$ and hence an increase of $\mathrm{pH}$ of the soil).

Though it remains questionable whether increased protein content in grass is desirable, the maintenance of a good soil reaction is certainly an advantage in so far as leaching losses will be diminished. Soils naturally high in $\mathrm{pH}$ present a problem however; on these, measures should be taken to check an increase of $\mathrm{pH}$, as this is likely to impede the circulation of certain minor elements, especially manganese, and possibly also cobalt. In the BPD-experiment these elements were on the borderline of deficiency in all plots and were clearly deficient in one or two plots of treatment I with a high $\mathrm{pH}$.

\section{Some considerations regarding the policy of fertilization in pastures}

In reviewing the whole experimental period of the BPD-investigation we came to the conclusion that the usual system of fertilization was satisfactory in an important respect, the maintenance of a good soil reaction. It appeared that on intensification the soil $\mathrm{pH}$ shows a slight increase; with moderate dressings of fertilizers the calcium stock in the soil is not seriously depleted and on intensification it is built up.

A contrast between organic manuring and inorganic fertilization need not be assumed because the amounts of organic manure available are in general insufficient to satisfy the needs of intensive agriculture. According to a recent estimate (KORTLEVEN and PivL, 1954) the amount of farmyard manure available for arable land and grassland in the Netherlands averages no more than 6 tons per ha per year. This leaves ample room for the use of inorganic fertilizers. There are of course small holdings of a purely pastoral type where the whole production of farmyard manure including of pigs and poultry goes to the pastures so that application of 20 tons per ha are quite possible. Such farms are more or less self-supporting in potash and phosphate but there may be problems with other elements, such as chlorine and sodium.

A favourable aspect of inorganic fertilizers is without doubt that they offer the possibility of increased formation of organic matter in the soil and of greater production of organic manure. The process can be reciprocal as increased use of farmyard manure and liquid manure keeps all kinds of nutrients $(\mathrm{N}, \mathrm{P}, \mathrm{K}$ and especially $\mathrm{Mg}$ ) circulating and this reduces the need for more intensive use of fertilizers.

Evidently there are vulnerable points in our usual system of fertilization in regard to the mineral elements, magnesium and sodium. The annual losses of magnesium 
are certainly not very great (possibly not more than $10 \mathrm{~kg}$ per ha), but the stock is very limited, at any rate in the sandy regions of our country. Actually it appeared that over a period of 11 years, even with very moderate applications of $N, P$ and $K$, the losses were such that the grass could no longer withdraw from the soil sufficient $\mathrm{Mg}$ for the needs of cattle. According to recent investigations (KEMP, 1960) the desirable minimum content in grass is $0,20 \% \mathrm{Mg}$.

It therefore seems essential to include magnesium regularly in the fertilization but the rate need not be very high if the soil has an adequate content of the element. SLUYSMANS (1962) put the desirable minimum of the magnesium content of the soil provisionally at $0,015 \% \mathrm{MgO}(=0,009 \% \mathrm{Mg}$, extractable with $\mathrm{NaCl})$. If this amount is present a light "maintenance" fertilization should be sufficient, not exceeding $100 \mathrm{~kg}$ kieserite per ha per annum or once every second year. Dolomitic limestone can also cause a rapid improvement of the $\mathrm{Mg}$ content of grass provided that it is finely ground so that it can be washed into the soil by the rain.

A grade of lime ammonium nitrate containing magnesium is obtainable at present in the Netherlands; it has a $\mathrm{MgO}$ content of $10 \%$ equivalent to $6 \% \mathrm{Mg}$. Fifty $\mathrm{kg} \mathrm{N}$ (250 kg fertilizer) thus supplies $15 \mathrm{~kg} \mathrm{Mg}$ and this is more than sufficient to replenish the annual loss. The choice of magnesium fertilizer should depend on the reaction of the soil.

Regarding sodium it can be concluded from the BPD-experiment that the application of large quantities is of no use as the soil has no pronounced capacity to build up a stock of sodium because of great leaching losses in winter; it is therefore advisable to supply to the sward every year an amount of sodium such that it will be practically exhausted at the end of the season.

It is known that the absorption of this element from potash salts is less than that from nitrate. A dressing of 40 per cent muriate of potash, for example, cannot maintain a sufficient sodium content in grass and the use of this salt even results in an increasing impoverishment in sodium as experience with treatment III of the BPD-experiment and in former investigations has shown. The most effective way of increasing the sodium content of grass appeared to be by using nitrate of soda (Chilean nitrate). It is not necessary for this purpose to apply this fertilizer all through the year as one dressing in spring is sufficient to ensure a reasonable content in the grass throughout the whole season (LEHR, 1960). Later nitrogen fertilization can then be applied as usual in the form of lime ammonium nitrate.

The application of common salt $(\mathrm{NaCl})$ as a fertilizer would be indicated in farms mainly applying organic manure, where the supply of chlorides is on the low side 1 owing to the omission of inorganic potash salts.

An objection which is raised occasionally against sodium fertilization of grass is that it lowers the calcium content. In the BPD-experiment this argument did not appear to be of great weight because the decrease of $\mathrm{Ca}$ content did not average more than 0,04 to $0,05 \%$ even with very intensive dressings of sodium (treatment $I$ ). This compares with an increase of $\mathrm{Na}$ content of one to two tenths of a per cent.

1 A detailed discussion of the chlorine problem would require more experimental material and consideration of the interactions between chloride and sulphate. It is mentioned as a matter of interest that the second author obtained favourable results with dressings of ammonium chloride on pastures on humic sandy soils with a high lime status (but remaining below $\mathrm{pH} 7$ ), when it served as a source of both nitrogen and chlorine, and at the same time improved the circulation of minor elements, especially manganese. 
It is nevertheless a problem in the Netherlands that the calcium contents of grass are often rather low. This need not necessarily be correlated with low contents of calcium in the soil but rather appears to be caused by our system of fertilization. The phenomenon could be partly explained by effects of high nitrogen fertilization on the percentage of clover and herbs, as apparent from the decreasing share of these constituents in the sward of the BPD-experiment (averaged over all treatments) :

$\begin{array}{cccc}\text { Year } & & \begin{array}{c}\text { Percentage } \\ \text { of clover }\end{array} & \begin{array}{c}\text { Percentage } \\ \text { of herbs }\end{array} \\ 1949 & \ldots & 3 & 10 \\ 1951 & \ldots & 4 & 11,5 \\ 1953 & \ldots & 3 & 9 \\ 1956 & \ldots & 1 & 5,5 \\ 1957 & \ldots & <1 & 2\end{array}$

On the other hand it may also be due to direct effects of our rather high applications of nitrogen and potash (the former also stimulating the uptake of potassium, possibly at the cost of calcium) or of the often high phosphate. status of our soils.

It is therefore desirable to study the uptake of calcium and the course of the $\mathrm{Ca}: \mathrm{P}$ ratio in grass under the influence of phosphate fertilization. The trend in the BPDexperiment is shown in TABLE 6 .

As the figures for grass in TABLE 6 are all for samples taken in May this may account in part for a lowered $\mathrm{Ca}$ content; the development of grass samples taken from different plots throughout the season in 1958 showed an average Ca content of $0,37 \%$ as against $0,31 \%$ early in May of that year.

TABLE 6. Effect of phosphate fertilization on uptake of calcium and on $\mathrm{Ca}: \mathrm{P}$ ratio in grass; averages of all treatments

\begin{tabular}{|c|c|c|c|c|c|}
\hline \multirow[t]{2}{*}{ Period } & \multirow{2}{*}{$\begin{array}{c}\text { Soil } \\
\text { P(citr.) }\end{array}$} & \multicolumn{4}{|c|}{ Crop } \\
\hline & & $\underset{(\%)}{\mathbf{P}}$ & $\begin{array}{c}\mathrm{Ca} \\
(\%)\end{array}$ & $\mathrm{Ca}: \mathrm{P}$ & Nature \\
\hline $1946-47$ & - & 0,31 & 0,415 & 1,34 & hay \\
\hline $1949-50$ & 103 & 0,385 & 0,39 & 1,00 & hay \\
\hline $1951-53$ & 98 & 0,50 & 0,44 & 0,88 & grass \\
\hline $1954-56$ & (133) 1 & 0,37 & 0,37 & 1,00 & grass and hay \\
\hline $1957-58$ & 121 & 0,49 & 0,29 & 0,59 & grass \\
\hline
\end{tabular}

1 This figure seems to be rather high, probably due to seasonal influences.

Part of the effect of decreasing $\mathrm{Ca}$ contents seems to be related to the $\mathbf{P}$ (citric) status of the soil which showed a clear increase during the later years of the experiment. Although this apparently did not result in an increase of phosphate content in hay and grass, it is correlated with a decrease of $\mathrm{Ca}$ content and of the $\mathrm{Ca}: \mathrm{P}$ ratio, especially in the period of intensification. It should be noted that the trend is general and is independent of the treatment applied.

The treatment with organic manure (II) always showed the highest figure for available $P$ (water-extractable). The increase of the $P$ (citric) figures is especially noticeable as no inorganic phosphate was applied in treatment II after 1950. The increasing stock of phosphate can therefore only be explained from the introduction of 
phosphate, taken up during the stall feeding and brought to the land with stable manure. The fact that there was also an increase of the soil stock of phosphate in treatments I and III follows from the fact that inorganic phosphate was applied, equalling the amounts of $\mathrm{P}$ in farmyard manure.

The amount of phosphate applied during the first period of 11 years $(24 \mathrm{~kg}$ per ha per annum) was in our experiment sufficient to replace the yearly withdrawal (estimated at $16-18 \mathrm{~kg} \mathrm{P}$ ) and to keep the stock of phosphate in the soil constant. During the period of intensification the average dosage of $41 \mathrm{~kg} \mathrm{P}$ per ha per annum apparently led to an increase of this stock.

With regard to the potassium economy of grassland it again appeared from the present investigation that grass readily absorbs the potassium placed at disposal, and that this easily results in luxury consumption. Especially with the use of farmyard manure and liquid manure the rate of application of potash should be fixed with great care.

As remarked under 3.4. preventing the soil $\mathrm{pH}$ from increasing too much, mainly due to nitrogen fertilization, is still a problem. In view of the $\mathrm{pH}$-raising effect of the $\mathbf{N}$ fertilizers commonly used in the Netherlands (lime ammonium nitrate in the old composition with $20,5 \% \mathrm{~N}$ and $38 \% \mathrm{CaCO}_{3}$ had the same effect) it seemed desirable to have a fertilizer available for correction of the above mentioned effect, say, sulphate of ammonia, ammonium sulphate nitrate or pure ammonium nitrate. With the use of the new composition of lime ammonium nitrate $(23 \% \mathrm{~N}, 33 \%$ $\mathrm{CaCO}_{3}$ ) little or no correction of the soil reaction will presumably be necessary. The question requires further study in connection with the problem of the circulation of minor elements.

BOSKMA, K.

KEMP, A.

Kortleven, J., and H. PuL

LEHR, J. J.

B. VEEN

SLUYSMaNs, C. M. J.

WIND, J., and W. B. DeYs

\section{LITER A T URE}

1958 Het effect van kalkammonsalpeter op de $\mathrm{pH}$ van de grond (Effect of lime ammonium nitrate on soil $\mathrm{pH}$ ). Stikstof. 2, 274-280.

1960 Hypomagnesaemia in milking cows: the response of serum magnesium to alterations in herbage composition resulting from potash and nitrogen dressings on pasture. Neth. J. agric. Sci. 8, 281-305.

1954 De voorziening van de grond met organische stof, voorheen en thans (Past and present supply of the soil with organic matter). Landbouwk. Tijdschr. 66, 90-98.

1960 The sodium content of meadow grass in relation to species and fertilization. Proc. Eighth Int. Grassland Congr. Reading, 1960. 101-103.

1952 Nitrogen economy of the soil in relation to seasonal and periodical climatic variations. Transaction of the Int. Soc. of Soil Sci. (Soil Fertility Meeting, Dublin, July 1952) Vol. II, 62-67.

1962 De magnesiumvoorziening van grasland (Magnesium supply of grassland) Lecture C.L.O. days, Utrecht, 14 February, 1962. Private communication. 